\title{
ANALISIS PENGARUH PENERAPAN ATRIBUTE CORPORATE GOVERNANCE TERHADAP TINGKAT KESEJAHTERAAN PEMEGANG SAHAM BANK-BANK UMUM
}

\author{
BAYU AJI \\ Dosen Pendidikan Ekonomi Universitas Pamulang \\ dosen2018@unpam.ac.id.
}

\begin{abstract}
ABSTRAK
Penelitian ini menguji apakah penerapan atribut tata kelola perusahaan memiliki dampak terhadap kekayaan pemegang saham bank komersial. Kami berhipotesis bahwa persentase dewan independen, keberadaan komite audit, struktur kepemilikan, jumlah dewan direksi, profitabilitas bank komersial, dan ukuran bank komersial, sebagai perwakilan dari tata kelola perusahaan, memiliki dampak terhadap kekayaan pemegang saham bank umum. Penelitian ini menggunakan beberapa atribut tata kelola perusahaan yang dikembangkan oleh Bursa Efek Indonesia (BEI) dan Badan Pengawas Pasar Modal, dan kekayaan pemegang saham bank komersial yang dikembangkan oleh Brigham dan Houston (2001). Menurut pendekatan Generalized least squared pada pooling data. Secara keseluruhan, menggunakan profitabilitas dan ukuran perusahaan sebagai variabel pengendali, hasil bahwa kekayaan pemegang saham bank komersial memiliki hubungan negatif dengan sebagian besar atribut tata kelola perusahaan, tetapi memiliki hubungan positif dengan jumlah dewan direksi. Penelitian ini memiliki beberapa implikasi untuk ditawarkan, salah satunya adalah dapat diambil sebagai pedoman bagi pemegang saham dan manajemen bank komersial. Selain itu, penelitian ini memberikan beberapa informasi dan identitas sumber ineficency, yang pada gilirannya dapat digunakan untuk membantu manajemen bank komersial untuk meningkatkan kekayaan pemegang saham.
\end{abstract}

Kata Kunci: Corporate Governance, Kesejahteraan, Bank 


\section{PENDAHULUAN}

Akuntansi sebagai bahasa bisnis yang digunakan sebagai salah satu alat untuk melaporkan kinerja manajemen dalam bentuk kuantitatif tidak dapat dilepaskan peranannya dalam pelaksanaan mekanisme corporate governance. Karena para pemegang saham, kreditur, dan stakeholders yang lain menggunakan laporan keuangan yang disusun oleh manajemen sebagai bahan untuk mengevaluasi kinerja dan laporan keuangan merupakan bentuk pertanggungjawaban manajemen atas penggunaan sumber daya dalam proses operasional perusahaan.

Secara teoritis praktik good corporate governance dapat meningkatkan nilai perusahaan dengan meningkatkan kinerja keuangan mereka, mengurangi risiko yang mungkin dilakukan oleh menajemen perusahaan dengan keputusan-keputusan yang menguntungkan diri sendiri dan pada akhirnya hal-hal tersebut dapat meningkatkan kesejahteraan para pemegang saham. Sebaliknya corporate governance yang buruk dapat menurunkan tingkat kepercayaan investor. Hal ini didukung oleh survei yang dilakukan McKinsey \& Co, dimana hasil survei tersebut menyatakan bahwa corporate governance menjadi prioritas utama para investor selain kinerja finansial dan potensi pertumbuhan, khususnya bagi pasarpasar yang sedang berkembang.
Dimata para investor, Indonesia dipandang sebagai salah satu negara di Asia yang terburuk dalam kualitas penerapan good corporate governance (McKinsey \& Co, 2002). Di sisi lain hasil survei tersebut juga menunjukan kesediaan para investor untuk membayar nilai premium bagi perusahaan-perusahaan yang telah menerapkan standar-standar corporate governance yang tinggi.

Dalam usahanya menciptakan praktik good corporate governance di Indonesia, pemerintah melalui Kementerian BUMN, Badan Pengawas Pasar Modal (BAPEPAM) dan Direksi Bursa Efek Indonesia (BEI) telah mewajibkan BUMN dan emiten untuk menerapkan kebijakan good corporate governance yang bertujuan untuk menciptakan kepastian hukum yang bermuara kepada perlindungan investor dan masyarakat.

Kita bisa melihat hal ini dengan membaca Keputusan Menteri BUMN nomor 117/2002 tentang Pengembangan Praktik Good Corporate Governance dalam perusahaan BUMN, untuk emiten dapat kita lihat melalui Surat Edaran Ketua BAPEPAM nomor SE03/PM/2000 dan Keputusan Direksi BEI nomor Kep-339/BEI/07-2001 yang mengharuskan semua perusahaan yang tercatat di Bursa Efek Indonesia memiliki komite audit dan komisaris independent Seperti yang diuraikan di atas, telah disebutkan berbagai alasan mengapa 
perusahaan-perusahaan perlu menerapkan konsep good corporate governance. Salah satu alasan utama penerapan konsep good corporate governance adalah untuk meningkatkan kepercayaan investor atau pemegang saham. Dari alasan tersebut ada tiga poin pertanyaan yang perlu dijawab

a. Bagaimana kepercayaan investor dapat muncul?

b. Apakah investor memperoleh return yang riil dari investasi mereka pada perusahaan yang telah menerapkan good corporate governance?

c. Apakah konsep good corporate governance dapat meningkatkan kinerja finansial perusahaan yang pada akhirnya dapat meningkatkan kesejahteraan yang diterima pemegang saham akibat dari peningkatan kinerja manajemen?

Konsep pemisahan antara pemilik dan pengelola perusahaan dapat menimbulkan masalah-masalah baru. Masalah yang sering muncul yaitu ketika manajemen lebih mengutamakan kepentingannya daripada kepentingan pemegang saham. Mekanisme corporate governance diciptakan untuk membentuk hubungan yang lebih baik antara manajemen dengan pemegang saham. Penerapan mekanisme ini dapat memberikan jaminan bahwa manajemen akan bekerja untuk kepentingan perusahaan dan pemegang saham. Berdasarkan hal tersebut dan latar belakang masalah yang telah disampaikan sebelumnya, permasalahan yang akan diuji dalam penelitian ini dirumuskan sebagai berikut:

Apakah penerapan mekanisme corporate governance memiliki pengaruh terhadap tingkat kesejahteraan pemegang saham? Penelitian ini mencoba menjawab pertanyaan di atas dengan menghubungkan data akuntansi yang diterbitkan perusahaan dan kinerja pasar dari harga saham perusahaan dengan karakteristik mekanisme corporate governance.

Penelitian ini dimaksudkan untuk menganalisis pengaruh penerapan mekanisme corporate governance terhadap tingkat kesejahteraan yang diterima oleh para pemegang saham, dimana mekanisme corporate governance berfungsi sebagai peraturan yang mengatur hubungan antara pemegang saham dengan manajemen dan sebagai alat untuk menjamin bahwa manajemen bekerja untuk kepentingan para pemegang saham. Pemegang saham mendelegasikan wewenang pengawasan dan pengendalian terhadap kinerja manajemen kepada dewan komisaris.

Komite audit merupakan bagian dari dewan komisaris yang melakukan fungsi tersebut. Sejalan dengan penyampaian tujuan di atas, 
maka manfaat yang diharapkan dari penelitian ini adalah:

1. Memberikan informasi yang lebih baik dan tidak menyesatkan guna menilai potensi dan kinerja perusahaan sehingga dapat digunakan sebagai dasar pengambilan keputusan investasi.

2. Sebagai bahan masukan, informasi dan landasan yang lebih kuat kepada perusahaanperusahaan di Indonesia mengenai perlu tidaknya penerapan mekanisme good corporate governance.

3. Memberikan tambahan informasi dan acuan untuk penelitian berikutnya terutama yang berhubungan dengan corporate governance.

4. Penelitian ini diharapkan dapat digunakan sebagai bahan referensi untuk penerapan corporate governance di masa yang akan datang dan dapat sebagai dasar untuk pengembangan konsep corporate governance secara lebih luas.

\section{METODE PENELITIAN}

\section{Pendekatan Penelitian}

Penelitian ini menggunakan data kualitatif dan kuantitatif. Data kualitatif didapat dari booklet, buku, jurnal, working paper yang berkaitan dengan konsep corporate governance. Sedangkan data kuantitatif didapat dari Indonesian
Capital Market Directory, annual report perusahaan, dan publikasi oleh Bursa Efek Indonesia. Data yang dipakai merupakan data sekunder yang meliputi:

a. Data laba bersih (net income) dan modal ekuitas (equity capital) dari perusahaan sampel untuk tahun 2002. Data ini diperoleh melalui laporan keuangan emiten yang dpublikasikan oleh Bursa Efek Indonesia.

b. Data return saham dan beta saham selama tahun 2002 dari perusahaan sampel yang diperoleh dari data base pasar modal PPA FE Universitas Gadjah Mada.

c. Data suku bunga Sertifikat Bank Indonesia (SBI) selama tahun 2002, diperoleh dari data base PPA FE Universitas Gadjah Mada.

d. Data mengenai keberadaan komite audit dan komisaris independen dari perusahaan sampel untuk tahun 2002 yang diperoleh dari data base Bursa Efek Indonesia.

e. Data kepemilikan saham oleh dewan direksi dan dewan komisaris selaku pengurus perusahaan yang diperoleh dari annual report masing-masing perusahaan.

f. Data mengenai jumlah dewan direksi dari perusahaan sampel yang diperoleh dari annual 
report masing-masing perusahaan.

\section{Sampel Penelitian}

Sampel menggunakan data tahun 2012-2016. Metode pengambilan sampel menggunakan purposive sampling dengan kriteria sebagai berikut:

a. Sampel yang diambil adalah perusahaan-perusahaan yang mencantumkan kepemilikan saham oleh dewan direksi dan dewan komisaris dalam annual report.

b. Perusahaan terdaftar di Bursa Efek Indonesia sebelum 31 Desember 2012 dan telah mengumumkan laporan keuangan sejak tanggal 31 Desember 2012.

c. Perusahaan-perusahaan yang belum maupun telah menerapkan corporate governance dengan indikator keberadaan komisaris independen dan komite audit, yang mengacu pada peraturan Bursa Efek Indonesia.

3. Variabel Penelitian

a. Economic Value Added (EVA) Untuk Mengukur Tingkat Kesejahteraan Pemegang Saham

$\begin{array}{lcr}\text { Untuk } & \text { mengukur } & \text { tingkat } \\ \text { kesejahteraan } & \text { yang } & \text { diterima } \\ \text { pemegang } & \text { saham } & \text { peneliti } \\ \text { menggunakan model economic value } \\ \text { added (EVA). Economic value added } \\ \text { adalah nilai tambah kepada }\end{array}$

pemegang saham atas hasil kinerja manajemen selama tahun tertentu (Brigham dan Houston, 2001). EVA merupakan kinerja keuangan yang dapat mengukur economic profit sebenarnya dari suatu perusahaan dibandingkan dengan ukuran kinerja keuangan lainnya. EVA juga merupakan ukuran kinerja yang paling terkait secara langsung dengan penciptaan kekayaan pemegang saham.

Manfaat utama dari EVA adalah penilaian kinerja perusahaan dimana fokus penilaian kinerja adalah penciptaan nilai. Penilaian kinerja dengan menggunakan pendekatan EVA menyebabkan perhatian manajemen lebih sesuai dengan pemegang saham. Oleh karena itu jika manajer berfokus pada EVA dapat membantu untuk menjamin bahwa manajemen bekerja secara konsisten untuk memaksimumkan kesejahteraan pemegang saham.

\section{b.Variabel Corporate Governance}

Penelitian ini menggunakan dua variabel corporate governance yang menekankan pada keberadaan komisaris independen, dan komite audit sebagai representatif dari pemegang saham dalam mengkontrol dan mengawasi kinerja manajemen. Penelitian ini juga memasukan variabel jumlah anggota dewan direksi, kepemilikan saham oleh komisaris dan direksi selaku pengurus perusahaan. Sesuai dengan penelitian Fuerst dan Kang (2000) 
mengenai corporate governance penelitian ini memasukan variabel log total aktiva sebagai indikator ukuran perusahaan, yang memiliki pengaruh terhadap variabel lainnya.

\section{c. Pembentukan Model Estimasi}

Penelitian ini menggunakan nilai economic value added dari setiap perusahaan untuk mengukur kesejahteraan yang diterima oleh para pemegang saham. Kemudian variabel-variabel independen di atas diuji pengaruhnya terhadap nilai EVA dari tiap-tiap perusahaan. Untuk melihat ada tidaknya efek ini, peneliti mengestimasi dengan metode Generalized least square (GLS) dengan menyusun model sebagai berikut:

\section{EVA $^{*}=\beta 0+\beta 1$ OUTDIR + $\beta 2$ STBOD $+\beta 3$ BODSIZE $+\beta 4$ ACEXIST + $\beta 5$ LNSIZE + e}

Karena

penelitian ini menggunakan metode regresi linear, maka agar model dapat digunakan untuk melakukan estimasi dan pengambilan kesimpulan mengenai populasi, perlu diuji validitasnya melalui pemenuhan asumsi klasik dan asumsi normalitas dari model tersebut. Ada beberapa asumsi klasik dan asumsi normalitas yang harus dipenuhi, yaitu: Heteroskedastisitas Multikolinearitas Autokorelasi Tes Normalitas.

\section{a. Hipotesis I}

Variabel OUTDIR sebagai
indikator persentase jumlah komisaris independen terhadap total jumlah anggota dewan komisaris, berdasarkan hasil uji t ( $\mathrm{t}$ : - $1.505 \mathrm{p}$ : 0.136) menunjukan pengaruh yang tidak signifikan terhadap economic value added (EVA). Dapat disimpulkan bahwa jumlah komisaris independen dalam struktur dewan komisaris tidak memiliki pengaruh terhadap tingkat kesejahteraan pemegang saham. Fuerst dan Kang (2000) dalam penelitiannnya menyatakan bahwa keberadaan outside directors (komisaris independen) tidak memiliki pengaruh terhadap kinerja operasional perusahaan dan memberikan pengaruh yang negatif terhadap nilai saham perusahaan

\section{b. Hipotesis II}

Keberadaan komite audit (ACEXIST) sebagai bagian dari mekanisme corporate governance, dari hasil uji t (t: $-1,375$ p: 0.1728$)$ menunjukan pengaruh yang tidak signifikan terhadap economic value added (EVA). Berdasarkan hasil tersebut keberadan komite audit tidak memiliki pengaruh terhadap tingkat kesejahteraan pemegang saham karena keberadaannya tidak memberikan nilai tambah kepada pemegang saham atas investasinya dalam perusahaan. 


\section{c. Hipotesis III}

Kepemilikan

saham

perusahaan oleh direksi dan komisaris (STBOD), dari hasil uji $\mathrm{t}$ (t:0.290 p: 0.7724) menunjukan pengaruh yang tidak signifikan terhadap economic value added (EVA). Penelitian ini menolak hipotesis yang menyatakan bahwa kepemilikan saham perusahaan oleh dewan direksi dan dewan komisaris memiliki pengaruh yang signifikan terhadap tingkat kesejahteraan pemegang saham.

\section{d. Hipotesis IV}

Hasil uji t (t: -0.131 p: 0.8959), menunjukan bahwa jumlah dewan direksi (BODSIZE) memiliki pengaruh yang tidak signifikan terhadap economic value added (EVA). Penelitian menolak hipotesis yang menyatakan bahwa jumlah dewan direksi memiliki pengaruh yang signifikan terhadap kesejahteraan pemegang saham. Hal ini disebabkan karena jumlah dewan direksi tidak memberikan pengaruh terhadap nilai tambah yang diperoleh pemegang saham atas investasinya pada perusahaan

\section{e. Hipotesis V}

Peneilitian ini menggunakan log total aktiva (LNSIZE) sebagai indikator ukuran perusahaan. Variabel tersebut memiliki fungsi sebagai variabel kontrol terhadap variabel-variabel lain dalam penelitian. Fuerst dan Kang (2000) menyatakan bahwa ukuran perusahaan memiliki pengaruh terhadap jumlah anggota outside diretors (komisaris independen) dan board of directors dalam perusahaan. Hasil uji t (t: 4.306 p: 0.000) menunjukan pengaruh positif yang signifikan dari ukuran perusahaan yang diproksikan dengan log total aktiva terhadap EVA untuk tingkat signifikansi 5\% pada uji dua sisi. Hasil ini dapat diartikan bahwa ukuran perusahaan memiliki pengaruh yang positif terhadap kesejahteraan pemegang saham, karena semakin besar ukuran perusahaan maka semakin besar pula nilai tambah yang diperoleh para pemegang saham atas investasinya pada perusahan.

\section{KESIMPULAN}

Penelitian ini dilakukan untuk mengetahui apakah mekanisme corporate governance dapat benarbenar memberikan jaminan kepada para pemegang saham atas hak-hak mereka dan untuk mengetahui apakah mereka memperoleh nilai tambah atas investasi mereka di perusahaan-perusahaan Indonesia. Sebagai alat untuk meneliti mekanisme corporate governance, penelitian ini menggunakan variabel persentase jumlah komisaris independen pada struktur dewan komisaris, keberadaan komite audit serta ditambah dengan karakteristik dari dewan direksi, yang diuji pengaruhnya terhadap economic 
value added (EVA) dari setiap perusahaan.

Alasan penggunaan variabel EVA sebagai indikator kesejahteraan pemegang saham, karena variabel tesebut dapat menunjukan nilai tambah yang diterima oleh para pemegang saham, dan hal ini sesuai dengan tujuan dari corporate governance, yaitu memberikan nilai tambah tambah bagi semua pihak yang berkepentingan (FCGI, 2001). Hasil uji statistik terhadap variabel komite audit (ACEXIST) dan komisaris independen (OUTDIR) menunjukan bukti bahwa penerapan peraturan BAPEPAM dan BEI yang mengharuskan perusahaanperusahaan di Indonesia memiliki komite audit dan komisaris independen sebagai bagian dari penerapan mekanisme corporate governance, belum dapat memberikan pengaruh yang positif terhadap kesejahteraan pemegang saham. Hasil penelitian menunjukan adanya indikasi atas penerapan mekanisme corporate governance sebagai berikut:

a. Hasil-hasil dari implementasi praktek corporate governance masih dianggap pelaporan kepada otoritas moneter, sehingga tidak adanya tindakan perbaikan dan monitoring kinerja rutin manajemen bank, diamana Peraturan BAPEPAM, BEI maupun Bank Indonesia yang mengharuskan perusahaanperusahaan yang tercatat di BEI memiliki komite audit dan komisaris independen. Pengaruh yang tidak signifikan atas penerapan mekanisme corporate governance terhadap kesejahteraan pemegang saham, menunjukan bahwa keberadaan komite audit dan komisaris independen belum difungsikan secara optimal karena seharusnya keberadaan kedua lembaga tersebut dapat memberikan manfaat kepada pemegang saham, yaitu pemegang saham akan merasa puas dengan kinerja perusahaan karena sekaligus akan meningkatkan shareholders value (FCGI, 2001).

b. Adanya kecenderungan pembentukan komisaris independen dan komite audit hanya untuk memenuhi peraturan yang berlaku dan untuk memberikan kesan kepada pemegang saham atau investor bahwa perusahaan-perusahaan di Indonesia telah menerapkan mekanisme corporate governance dengan baik. Sehingga kurangnya koreksi lansung atas temuan audit pada kinerja manajemen.

c. Selain menguji variabel-variabel yang berkaitan dengan mekanisme corporate governance, penelitian ini juga meneliti pengaruh dari karakteristik dewan direksi dan kepemilikan saham perusahaan 
oleh direksi dan komisaris terhadap kesejahteraan para pemegang saham. Hasil uji statistik, menunjukan bahwa jumlah anggota dewan direksi (BODSIZE) tidak memiliki pengaruh terhadap kesejahteraan pemegang saham. Untuk variabel STBOD yang menunjukan kepemilikan saham oleh pengurus perusahan, dari hasil uji statistik menunjukan pengaruh yang tidak signifikan terhadap kesejahteraan pemegang saham.

Penelitian ini menunjukan tidak adanya hubungan positif antara kepemilikan saham perusahaan oleh direksi dan komisaris terhadap kinerja perusahaan dan kesejahteraan pemegang saham, hasil tersebut juga menunjukan adanya indikasi bahwa pada perusahaan-perusahaan di Indonesia masih banyak mengalami masalah-masalah keagenan (agency problem). Variabel log total aktiva adalah variabel terakhir yang diuji dalam penelitian. Pengaruh positif yang signifikan menunjukan bahwa semakin besar ukuran perusahaan, maka semakin besar pula nilai tambah yang diperoleh pemegang saham atas investasinya dalam perusahaan.

\section{REFERENSI}

Alijoyo, Antonius, R. Djemat, Humphrey, Tjager, I Nyoman, Soembodo, Bambang, (2003). Corporate Governance: Tantangan dan Kesempatan Bagi Komunitas Bisnis di Indonesia. Jakarta: PT Prenhallindo.

Alijoyo, Antonius dan Zaini, Subarto, (2004). Komisaris Independen: Penggerak Praktik GCG di Perusahaan. Jakarta. PT Indeks,

Alijoyo, Antonius, (2003).

"Keberadaan dan Peran Komite

Audit Dalam Rangka

Implementasi GCG." Materi Seminar Nasional GCG, Surabaya.

Alijoyo, Antonius, (2002). Corporate Governance and Leadership Boards.

Egon Zehnder International, (2000). Corporate Governance and The Role of The Board of Directors.

Fama, E.F., (1980). "Agency Problems and The Theory of The Firm." Journal Political Economy, 88, 288-307.

FCGI, (2001). Corporate Governance. Jilid 1, Edisi ke-3.

FCGI, (2001). Peranan Dewan Komisaris dan Komite Audit Dalam Pelaksanaan Corporate Governance. Jilid 2, Edisi ke-2.

Fuerst ,Oren, and Kang, Sok-Hyon, (2000). "Corporate Governance, Expected Operating Performance and Pricing." Yale 
School of Management, New Haven.

Gujarati, Damodar N., (2003). Basic

Econometrics. 4th Edition, McGraw Hill Company, Singapore.

Houston, Joel F., and Brigham, Eugene F., (2001). Fundamentals of Financial Managements. Harcourt College Publishers Company, United States of America.

Jensen, M.C., (1993). "The Modern

Industrial Revolution, Exit, and The Failure of Internal Control System." Journal of Finance 48, 831-880.

Jogiyanto, H.M., (2003). Teori Portofolio dan Analisis

Investasi. Edisi ke-3, BPFE, Yogyakarta.

Keputusan Menteri BUMN

No.117/Tahun 2002 tentang

Penerapan GCG di Lingkungan BUMN.

Kusadrianto, Doddy. Menciptakan Persaingan Usaha yang Sehat Melalui Corporate Governance. Forum for Corporate Governance Indonesia.

Marrakchi Choutrou, S., Bedard, J., and Courteau, L., (2001). "Corporate Governance and Earnings Management." Social Scient Research Network (SSRN).

Mc Kinsey \& Company, (2002). Mc

Kinsey Global Investor Opinion

Survey.
Mitton, Tod, (2001). "A Cross-Firm Analysis of The Impact of Corporate Governance on The East Asian Financial Crisis." Marriott School of Management, Brigham Young University.

OECD, (1998). Business Sector Advisory Group on Corporate Governance.

OECD Principles of Corporate Governance.

Surat Edaran Ketua BAPEPAM nomor: SE-03/PM/2000 tentang Komite Audit.

Surat Direksi BEI nomor Kep.339/BEI/07-2001, Peraturan I-A tentang Ketentuan Umum Pencatatan Efek Bersifat Ekuitas di Bursa. 